\title{
Remote Optogenetic Activation and Sensitization of Pain Pathways in Freely Moving Mice
}

\author{
Ihab Daou, ${ }^{1,2}$ Alexander H. Tuttle, ${ }^{2,3}$ Geraldine Longo, ${ }^{2,4}$ Jeffrey S. Wieskopf, ${ }^{2,3}$ Robert P. Bonin, ${ }^{2,5}$ Ariel R. Ase, ${ }^{1,2}$ \\ John N. Wood, ${ }^{6}$ Yves De Koninck, ${ }^{2,5}$ Alfredo Ribeiro-da-Silva, ${ }^{2,4}$ Jeffrey S. Mogil,,3 and Philippe Séguéla ${ }^{1,2}$ \\ ${ }^{1}$ Montreal Neurological Institute, Department of Neurology and Neurosurgery, ${ }^{2}$ The Alan Edwards Centre for Research on Pain, and Departments of \\ ${ }^{3}$ Psychology and ${ }^{4}$ Pharmacology and Therapeutics, McGill University, Montreal, Canada, H3A 2B4, ${ }^{5}$ Quebec Mental Health Institute, Department of \\ Psychiatry and Neuroscience, Laval University, Quebec City, Canada, G1J 2G3, and ${ }^{6}$ Wolfson Institute for Biomedical Research, University College London, \\ London, United Kingdom, WC1E 6BT
}

We report a novel model in which remote activation of peripheral nociceptive pathways in transgenic mice is achieved optogenetically, without any external noxious stimulus or injury. Taking advantage of a binary genetic approach, we selectively targeted $\mathrm{Na}_{\mathrm{v}} 1.8^{+}$sensory neurons for conditional expression of channelrhodopsin-2 (ChR2) channels. Acute blue light illumination of the skin produced robust nocifensive behaviors, evoked by the remote stimulation of both peptidergic and nonpeptidergic nociceptive fibers as indicated by c-Fos labeling in laminae I and II of the dorsal horn of the spinal cord. A non-nociceptive component also contributes to the observed behaviors, as shown by c-Fos expression in lamina III of the dorsal horn and the expression of ChR2-EYFP in a subpopulation of large-diameter $\mathrm{Na}_{\mathrm{v}} 1.8^{+}$dorsal root ganglion neurons. Selective activation of $\mathrm{Na}_{\mathrm{v}} 1.8^{+}$afferents in vivo induced central sensitization and conditioned place aversion, thus providing a novel paradigm to investigate plasticity in the pain circuitry. Long-term potentiation was similarly evoked by light activation of the same afferents in isolated spinal cord preparations. These findings demonstrate, for the first time, the optical control of nociception and central sensitization in behaving mammals and enables selective activation of the same class of afferents in both in vivo and ex vivo preparations. Our results provide a proof-of-concept demonstration that optical dissection of the contribution of specific classes of afferents to central sensitization is possible. The high spatiotemporal precision offered by this noninvasive model will facilitate drug development and target validation for pain therapeutics.

\section{Introduction}

Pain is a subjective unpleasant sensory and emotional experience caused by noxious and/or potentially damaging stimuli. These stimuli are sensed by a group of primary sensory neurons called nociceptors (Basbaum et al., 2009; Dubin and Patapoutian, 2010). Many inflammatory, neuropathic, and cancer models have been developed to investigate acute and chronic pain, yet the interrogation of specific nociceptive functions in these models lacks spatiotemporal precision. Thus, the development of novel models in which the role of specific classes of sensory neurons in pain onset and processing can be investigated remains an unmet goal.

Furthermore, although ex vivo preparations have been very instrumental to study synaptic integration of sensory input at the

Received June 7, 2013; revised 0ct. 23, 2013; accepted Oct. 24, 2013.

Author contributions:I.D., A.H.T., J.S.W., R.P.B., Y.D.K., A.R.-d.S., J.S.M., and P.S. designed research; I.D., A.H.T. G.L., J.S.W., R.P.B., and A.R.A. performed research; J.N.W. contributed unpublished reagents/analytic tools; I.D., A.H.T., G.L., J.S.W., R.P.B., J.N.W., Y.D.K., A.R.-d.S., J.S.M., and P.S. analyzed data; I.D., R.P.B., J.S.M., and P.S. wrote the paper.

This work was supported by Canadian Institutes of Health Research Grants MOP86527 (P.S.), MOP79411 (A.R.-d.S.), and MOP12942 (Y.D.K.), a grant from the Pfizer-Le Fonds de la Recherche en Santé du Québec Innovation Fund (Y.D.K.), the Quebec Pain Research Network, and the Louise and Alan Edwards Foundation (J.S.M., P.S.).

The authors declare no competing financial interests.

Correspondence should be addressed to Philippe Séguéla, Montreal Neurological Institute, 3801 University, Suite 778, Montreal, Quebec, Canada, H3A 2B4. E-mail: philippe.seguela@mcgill.ca.

DOI:10.1523/JNEUROSCI.2424-13.2013

Copyright $\odot 2013$ the authors $\quad 0270-6474 / 13 / 3318631-10 \$ 15.00 / 0$ dorsal horn level (Dahlhaus et al., 2005; Fenselau et al., 2011; Yang et al., 2011), an important limitation in relating these results to in vivo data obtained in behaving animals lies in the inability to activate the same population of afferents, and with comparable parameters, across preparations.

An optogenetic strategy can be used to fill this gap and allow comparable activation of sensory fibers across all compartments: peripheral endings, cell body, axons, and central terminals. In rodents, transgenic expression of channelrhodopsin-2 (ChR2) driven by the Thy-1.2 promoter was used to optically activate broad classes of mechanoreceptors and proprioceptors, allowing the investigation of reflex behaviors, but the promoter used did not allow targeting of selective classes of afferents (Ji et al., 2012). Using a knock-in strategy, ChR2 expression in nonpeptidergic Mas-related G-protein-coupled receptor member D-positive $\left(\mathrm{Mrgprd}^{+}\right)$nociceptors has been used to investigate their connectivity in the substantia gelatinosa of the mouse spinal cord. However, this study did not report any lightinduced nocifensive behaviors in the Mrgprd-ChR2 transgenic mice (Wang and Zylka, 2009), presumably because the Mrgprd promoter is unable to drive sufficient expression of ChR2 channels in peripheral sensory endings. Thus, the development of a transgenic mammalian model in which pain pathways are optogenetically controlled in all compartments of sensory fibers remains unachieved, precluding precise control of inputs in behaving animals.

Here, we took advantage of the $N a_{v} 1.8-C r e$ recombinase knock-in mouse line generated by Stirling et al. (2005) to selec- 
tively deliver ChR2 to $\mathrm{Na}_{\mathrm{v}} 1.8^{+}$nociceptors $\left(\mathrm{Na}_{v} 1.8-\mathrm{ChR} 2^{+}\right)$. $\mathrm{Na}_{\mathrm{v}} 1.8$ is a subtype of voltage-gated sodium channels expressed in almost all nociceptors (Shields et al., 2012), and $\mathrm{Na}_{\mathrm{v}} 1.8$ expressing neurons have been shown to play important roles in inflammatory and chronic pain conditions (Lai et al., 2002; Joshi et al., 2006; Abrahamsen et al., 2008). This strategy allowed the conditional expression of $\mathrm{ChR} 2$ driven by the strong CAG promoter, thus overcoming the limitation of low opsin levels. $\mathrm{Na}_{v} 1.8-\mathrm{ChR}_{2}{ }^{+}$transgenic mice showed robust nocifensive behaviors under blue-light stimulation of the skin, demonstrating that pain can be light-induced in freely moving mammals. Prolonged exposure to blue light caused central sensitization manifested by thermal and mechanical hypersensitivity in behaving mice, as well as long-term potentiation (LTP) in spinal slice preparations with roots attached, providing evidence that nociception and central plasticity can be optically and remotely induced by selective activation of $\mathrm{Na}_{\mathrm{v}} 1.8^{+}$afferents, in the absence of neurogenic inflammation and without any invasive stimulation affecting peripheral tissues, and across preparations.

\section{Materials and Methods}

Subjects. Adult mice (1-4 months of age) of both sexes, weighing 20-35 $\mathrm{g}$, were used in this study. Mice were housed in the animal care facilities of the Montreal Neurological Institute, McGill University, and the Centre de Recherche de l'Université Laval Robert-Giffard, Laval University. Animals were kept on a $12 \mathrm{~h}$ light/dark cycle, with food and water provided ad libitum. All experimental procedures were approved by the Animal Care and Use Committees at McGill University and Laval University, in accordance with the regulations of the Canadian Council on Animal Care.

Mouse line production. The genetic construction and generation procedure of the $\mathrm{Na}_{v} 1.8$-Cre driver mice were described previously (Stirling et al., 2005). Homozygous $\mathrm{Na}_{v} 1.8-\mathrm{Cre}$ mice were crossed with heterozygous Ai32 mice (C57BL/6 background) purchased from The Jackson Laboratory. These Ai32 mice carry the ChR2(H134R)-EYFP gene in their Gt(ROSA)26Sor locus (Madisen et al., 2012). The gene is separated from its CAG promoter by a loxP-flanked transcriptional STOP cassette, allowing its expression in a Cre-dependent manner. Mice carrying TauEGFP in their ROSA26 locus were kindly provided by Dr. Ulrich Boehm (University of Hamburg, Hamburg, Germany) and have a similar genetic construction as the Ai32 mice.

Immunofluorescence. Mice were deeply anesthetized with Equithesin ( $6.5 \mathrm{mg}$ of chloral hydrate and $3 \mathrm{mg}$ of sodium pentobarbital in a volume of $0.3 \mathrm{ml}$, i.p., per $100 \mathrm{~g}$ body weight) and then intracardially perfused with $50 \mathrm{ml}$ of perfusion buffer, followed by $250 \mathrm{ml}$ of $4 \%$ paraformaldehyde (PFA) in $0.1 \mathrm{~m}$ phosphate buffer (PB), $\mathrm{pH} 7.4$, at room temperature for $30 \mathrm{~min}$. Dorsal root ganglia (DRG), trigeminal ganglia (TG), spinal cord, sciatic nerve, and glabrous skin were extracted and postfixed in $4 \%$ PFA for $1 \mathrm{~h}$ at $4^{\circ} \mathrm{C}$. Tissue was then cryoprotected in $30 \%$ sucrose in PB overnight at $4^{\circ} \mathrm{C}$. To study the spinal cord and glabrous skin, $40-\mu \mathrm{m}-$ thick sections were cut at $-20^{\circ} \mathrm{C}$ using a cryostat (Leica). All sections were collected as free floating in PBS with $0.2 \%$ Triton X-100 (PBS-T). As for the DRGs, TGs, and sciatic nerves, sectioning at $14 \mu \mathrm{m}$ thickness was performed directly onto gelatin-subbed slides. Sections were initially permeabilized with $50 \%$ ethanol for $30 \mathrm{~min}$, followed by 1 min incubation in a $0.3 \%$ hydrogen peroxide solution. Sections were washed in PBS-T for 30 min between all incubations. Nonspecific binding of the secondary antibody was blocked by pretreating the sections for $1 \mathrm{~h}$ at room temperature in $10 \%$ normal goat and donkey serum (Invitrogen) diluted in PBS. The sections were then incubated at $4^{\circ} \mathrm{C}$ for $24 \mathrm{~h}$ with a rabbit anti-calcitonin gene-related protein (CGRP) antibody (Sigma) and a guinea pig anti-purinoceptor P2X3 antibody (Neuromics) at a dilution of 1:2000 and 1:25,000, respectively. To control for nonspecific staining, the primary antibodies were omitted, which resulted in the abolishment of specific signal for all antibodies used. After several rinses in PBS-T, sections were incubated for $90 \mathrm{~min}$ at room temperature with a biotin-conjugated donkey anti-guinea pig IgG (1:200; Jackson Immu-
noResearch) in PBS, followed by additional signal amplification via tyramide (1:75; PerkinElmer Life and Analytical Sciences) for 7 min. The sections were incubated for $2 \mathrm{~h}$ at room temperature with a mixture of streptavidin conjugated to Alexa Fluor 568 (1:200; Invitrogen) and highly cross-absorbed goat anti-rabbit IgG conjugated to Alexa Fluor 647 (1:800; Invitrogen) in 5\% normal goat and donkey serum in PBS-T. Finally, the sections were washed, mounted on gelatin-subbed slides (spinal cord and glabrous skin), air dried, and coverslipped with an antifading mounting medium (Aqua PolyMount; Polysciences). Slides were stored at $4^{\circ} \mathrm{C}$ until examined. The fluorescence of transgenic ChR2EYFP was sufficiently strong to be visualized in the triple labeling. The morphology of all the different tissues was analyzed with a Zeiss LSM 710 confocal microscope equipped with argon and helium-neon lasers. All triple labeling confocal micrographs were obtained with either $20 \times$ or $40 \times$ oil-immersion objective lenses. For the glabrous skin sections, to increase the number of in-focus immunoreactive structures, several images were taken at different focal planes ( $Z$-stack) and merged into one horizontal projection. Images were processed in Adobe Photoshop 7 (Adobe Systems) to optimize brightness and contrast. For marker overlap quantification, confocal micrographs of eight different DRG sections per animal were analyzed to assess the colocalization of ChR2-EYFP with the nociceptive markers P2X3 and CGRP.

Cell culture and DRG preparation. DRGs were extracted from adult $\mathrm{Na}_{v} 1.8-\mathrm{ChR}^{+}$mice, $\mathrm{Na}_{v} 1.8-\mathrm{Cre}$ mice, or adult transgenic mice expressing Tau-EGFP in the $\mathrm{Na}_{\mathrm{v}} 1.8^{+}$neurons $\left(\mathrm{Na}_{v} 1.8-\mathrm{Tau}^{+}\right)$and kept in sterile ice-cold $1 \times$ HBSS medium (Invitrogen) throughout the dissection. $\mathrm{Na}_{v} 1.8-\mathrm{Tau}^{+}$and $\mathrm{Na} a_{v} 1.8$-Cre mice were used as negative control. DRGs were then incubated in $5 \mathrm{ml}$ HBSS containing $1.4 \mathrm{mg} / \mathrm{ml}$ dispase (Sigma-Aldrich) and $1.1 \mathrm{mg} / \mathrm{ml}$ collagenase type II (Sigma-Aldrich) for $30 \mathrm{~min}$ at $37^{\circ} \mathrm{C}$ and $5 \% \mathrm{CO}_{2}$. After the enzymatic reaction, DRGs were washed twice with $10 \mathrm{ml}$ of culture media (F-12 media (Invitrogen), with $10 \%$ FBS, $1 \%$ L-glutamine, $1 \%$ penicillin, and $1 \%$ streptomycin). DRGs were then mechanically triturated using fire-polished Pasteur pipettes. Mechanical trituration was repeated five times. After each trituration, ganglia were briefly centrifuged ( $1000 \mathrm{rpm}$ maximum), and the supernatant was collected. The dissociated neurons were finally plated onto five $35-\mathrm{mm}$ culture dishes (Starsted; $2 \mathrm{ml} /$ dish) coated previously with laminin (BD Bioscience) and poly-D-lysine (Sigma-Aldrich). Cells were incubated for $24 \mathrm{~h}$ at $37^{\circ} \mathrm{C}$ and $5 \% \mathrm{CO}_{2}$ before electrophysiological recording.

Whole-cell electrophysiology. Whole-cell patch-clamp recordings on DRG neurons were conducted at room temperature $24 \mathrm{~h}$ after plating. The internal solution of the pipette, $\mathrm{pH} 7.2$, contained the following (in $\mathrm{mm}$ ): $130 \mathrm{~K}$-gluconate, $1 \mathrm{MgCl}_{2}$, 10 HEPES, 5 EGTA, $3 \mathrm{MgATP}$, and 0.4 GTP. Bath solution, $\mathrm{pH}$ 7.4, contained the following (in mM): $152 \mathrm{NaCl}$, $5 \mathrm{KCl}, 2 \mathrm{CaCl}_{2}, 1 \mathrm{MgCl}_{2}, 10 \mathrm{HEPES}$, and 10 glucose. Patch pipettes had a tip resistance of 5-10 M . Electrophysiological recordings were conducted using an Axopatch 200B amplifier, digitized with a Digidata 1322A interface (Molecular Devices). Traces were acquired and analyzed using pClamp 8.2 software (Molecular Devices). Recordings were lowpass filtered at 2 and $5 \mathrm{kHz}$ in voltage- and current-clamp configurations, respectively. A multimode optic fiber (200 $\mu \mathrm{m}$ diameter; Thorlabs), coupled to a diode-pumped solid-state laser of specific wavelength $(473 \mathrm{~nm}$ blue or $590 \mathrm{~nm}$ yellow laser; Laserglow Technologies), was used for optical stimulation of DRG neurons. Light intensities were measured using a PM100A power meter coupled to a S130C photodiode sensor (Thorlabs) and analyzed using LabVIEW 8.5 software. A series of 1 s hyperpolarizing current injections ( 0 to $-150 \mathrm{pA})$ in $50 \mathrm{pA}$ steps was used to measure the input resistance $\left(R_{\mathrm{in}}\right)$ of $\mathrm{ChR} 2^{+}$and ChR2-negative $\left(\mathrm{ChR} 2^{-}\right)$small-diameter DRG neurons.

Acute pain experiments. $\mathrm{Na}_{v} 1.8-\mathrm{ChR}_{2}{ }^{+}$and $\mathrm{Na}_{v} 1.8-\mathrm{Tau}^{+}$mice were habituated for $1 \mathrm{~h}$ in transparent Plexiglas cubicles $(10 \times 6.5 \times 6.5 \mathrm{~cm})$ set atop a $1 / 2$-inch glass floor and separated from each other by opaque dividers. Acute nociceptive behaviors were elicited using a pulsing laser (473 nm blue or $590 \mathrm{~nm}$ yellow light at 2, 5, and $10 \mathrm{~Hz}$ ) set at different intensities and aimed at the left plantar hindpaw. Animals were tested for a total of five trials of $20 \mathrm{~s}$ duration each, with at least $3 \mathrm{~min}$ between trials. Scored nocifensive behaviors included purposeful hindpaw withdrawal, hindpaw licking, jumping, and audible vocalization. The percentage of 
trials during which these behaviors occurred is reported. If a mouse displayed all four behaviors during the $20 \mathrm{~s}$ trial, the trial was immediately halted.

To determine the effects of analgesic drugs on light-elicited behaviors, $\mathrm{Na}_{v} 1.8-\mathrm{ChR} 2^{+}$mice were tested using blue laser light as described above, at a $10 \mathrm{~Hz}$ pulsing frequency. After baseline testing, mice were injected intraperitoneally with morphine $(10 \mathrm{mg} / \mathrm{kg})$ or pregabalin $(300 \mathrm{mg} / \mathrm{kg})$ before retesting. These doses were chosen as doses not causing ataxia on the rotarod test in this strain.

c-Fos immunostaining. $\mathrm{Na}_{v} 1.8-\mathrm{ChR} 2^{+}$mice were habituated for $2 \mathrm{~h}$ in the same setup used for acute pain experiments. The plantar surface of the left hindpaw (ipsilateral) was then stimulated for $10 \mathrm{~min}$ with suprathreshold $\left(1.27 \mathrm{~mW} / \mathrm{mm}^{2}\right)$ blue laser light $(473 \mathrm{~nm})$, pulsed at $10 \mathrm{~Hz}$. Mice were given $30 \mathrm{~s}$ breaks between stimulations during the 10 min test. At $1-1.5 \mathrm{~h}$ after stimulation, mice were anesthetized and perfused as described previously, and the lumbar spinal cord was extracted (L3-L5 segments). Serial sections were cut at a thickness of $40 \mu \mathrm{m}$ using a cryostat and subsequently immunoprocessed with a rabbit c-Fos polyclonal antibody (1:800; sc-52, lot \#J1712; Santa Cruz Biotechnology). Sections were then incubated with a biotinylated goat anti-rabbit IgG Alexa Fluor 594 secondary antibody (1:800; A11037, lot \#982447; Invitrogen).

Using a Zeiss LSM 710 confocal microscope, we quantified the number of c-Fos ${ }^{+}$neurons specifically in the superficial laminae (I-III) of the spinal gray matter. We captured photomicrographs of 10 sections per animal on both ipsilateral and contralateral sides. The average number of $\mathrm{c}-\mathrm{Fos}^{+}$neurons per section was used for statistical analysis. Statistical significance was analyzed using an unpaired Student's $t$ test in GraphPad Prism 6 (GraphPad Software).

Thermal and mechanical hypersensitivity. In these experiments, the left and right hindpaws of $\mathrm{Na}_{v} 1.8-\mathrm{ChR2}{ }^{+}$and $\mathrm{Na}_{v} 1.8-\mathrm{Tau}^{+}$mice were tested for sensitivity to thermal and mechanical stimuli before and after $(1,5$, and $24 \mathrm{~h}$ after) a prolonged ( $30 \mathrm{~min})$, suprathreshold $(2.34 \mathrm{~mW} /$ $\mathrm{mm}^{2}$ ) blue-light stimulation of the left hindpaw. The nonstimulated right hindpaw was used as an internal control. Mice were anesthetized with $2.5 \%$ isoflurane during the $30 \mathrm{~min}$ stimulation. Laser was pulsed at $2 \mathrm{~Hz}$ with $100 \mathrm{~ms}$ pulse duration. Before testing, mice were habituated for $1 \mathrm{~h}$ in transparent Plexiglas cubicles $(10 \times 6.5 \times 6.5 \mathrm{~cm})$ set atop a $1 / 2$-inch glass floor (for thermal testing) or atop a perforated metal floor (with 5-mm-diameter holes $7 \mathrm{~mm}$ apart; for mechanical testing) and separated from each other by opaque dividers. Thermal sensitivity was measured using the radiant heat paw withdrawal test (Hargreaves et al., 1988). In this test, an orange-red filter was placed on the light source to prevent its blue component from activating $\mathrm{ChR} 2$ and interfering with the thermal threshold measurements. Mechanical sensitivity was assessed using an automated von Frey fiber with automatically increasing force (Ugo Basile Dynamic Plantar Aesthesiometer) applied to the midplantar hindpaw. In both tests, three separate withdrawal latency or threshold determinations were taken on each hindpaw at each time point. Data were averaged for each hindpaw at each time point across 12 animals, and comparison was done between each poststimulation time point and baseline measurements (prestimulation), using the repeatedmeasures one-way ANOVA test in GraphPad Prism 6.

Plasma extravasation. $\mathrm{Na}_{v} 1.8-\mathrm{ChR} 2^{+}$mice were used to determine whether prolonged blue-light stimulation induces neurogenic inflammation, and $\mathrm{Na}_{v} 1.8-\mathrm{Tau}^{+}$mice were used to assess capsaicin-induced neurogenic inflammation as a positive control. All subjects were injected with Evans blue $(50 \mathrm{mg} / \mathrm{kg}$, i.v.) before any treatment. Twenty microliters of capsaicin $(1 \%)$ and saline were subdermally injected in the left and right hindpaws of $\mathrm{Na}_{v} 1.8-\mathrm{Tau}^{+}$mice, respectively. In $\mathrm{Na}_{v} 1.8-\mathrm{ChR2}{ }^{+}$ mice, prolonged suprathreshold (30 $\mathrm{min}, 2.34 \mathrm{~mW} / \mathrm{mm}^{2}$ ) blue-light stimulation of the left hindpaw was conducted as described previously, whereas the right hindpaw remained unstimulated as an internal control. This stimulation paradigm is the same one used to induce long-term hypersensitivity. Forty-five minutes after treatment, animals were intracardially perfused with saline to clear out the blood. The hindpaws were then cut off $0.5 \mathrm{~cm}$ below the ankle and placed in $5 \mathrm{ml}$ of formamide at $60^{\circ} \mathrm{C}$ for $48 \mathrm{~h}$ to extract the Evans blue dye. The concentration of the extracted dye was then measured spectrophotometrically at $620 \mathrm{~nm}$. Ev- ans blue concentration in each condition was normalized to its appropriate internal control.

Spinal cord electrophysiology. The lumbar spinal column was removed from adult $\mathrm{Na}_{v} 1.8-\mathrm{ChR2} 2^{+}$male mice and immersed in ice-cold sucrosesubstituted artificial CSF (aCSF; $252 \mathrm{~mm}$ sucrose, $2.5 \mathrm{~mm} \mathrm{KCl}, 1.5 \mathrm{~mm}$ $\mathrm{CaCl}_{2}, 6 \mathrm{mM} \mathrm{MgCl}_{2}$, and $10 \mathrm{~mm}$ D-glucose, bubbled with $95 \%$ oxygen $/ 5 \%$ $\mathrm{CO}_{2}$ ), after which the whole lumbar spinal cord was quickly removed via laminectomy. Ventral roots and connective tissue were removed from the spinal cord, and the tissue was placed in room-temperature aCSF (126 mM NaCl, $2.5 \mathrm{~mm} \mathrm{KCl}, 2 \mathrm{~mm} \mathrm{CaCl}, 2 \mathrm{~mm} \mathrm{MgCl}_{2}$, and $10 \mathrm{~mm}$ D-glucose, bubbled with $95 \%$ oxygen $/ 5 \% \mathrm{CO}_{2}$ ) for $1 \mathrm{~h}$ before experimentation. During experiments, the tissue was perfused with aCSF at room temperature at a flow rate of $8-10 \mathrm{ml} / \mathrm{min}$. Dorsal root field potentials (DFPs) were recorded via a borosilicate glass electrode inserted into the dorsal side of the spinal cord in the dorsal root entry zone. Electrodes were inserted to a depth of no more than $100 \mu \mathrm{m}$ from the dorsal surface of the spinal cord measured with an MPC-200 manipulator (Sutter Instruments). Electrodes had a tip resistance of 3-4 M $\Omega$ when filled with aCSF. DFPs were evoked by stimulating the dorsal root most proximal to the recording electrode with a focused spot of $488 \mathrm{~nm}$ laser light (iBeam Smart PT; Toptica Photonics) $\sim 1 \mathrm{~mm}$ in diameter, 3-4 $\mathrm{mm}$ from the dorsal root entry zone. The frequency of laser pulses (10 ms duration, 1.5 $\mathrm{mW}$ ) was controlled with TopControl software (Toptica Photonics). Field potentials were amplified with a Multiclamp 700B amplifier (Molecular Devices), digitized with a Digidata 1322A (Molecular Devices), and recorded using pClamp 10 software (Molecular Devices). Data were filtered during acquisition with a low-pass filter set at $1.6 \mathrm{kHz}$ and sampled at $10 \mathrm{kHz}$.

Test pulses of light were presented every $60 \mathrm{~s}$ to evoke DFPs before and after LTP induction. LTP was induced by low-frequency stimulation of the dorsal root $(2 \mathrm{~Hz}, 2 \mathrm{~min}, 2 \mathrm{~mW}$ ) as described previously (Ikeda et al., 2006). In some experiments, DL-2-amino-5-phosphonopentanoic acid (APV; Sigma-Aldrich) was added to the perfusion solution $10 \mathrm{~min}$ before LTP induction and washed out immediately after the stimulation protocol. The $10 \mathrm{~min}$ period immediately before the addition of APV was used for baseline in these experiments, and all data presented here represent DFP measured in the absence of APV.

Data were analyzed using ClampFit 10 software (Molecular Devices). The area of DFPs relative to baseline was measured from 0 to $1000 \mathrm{~ms}$ after the onset of the DFP. Data from the last $5 \mathrm{~min}$ of baseline and from 55 to $60 \mathrm{~min}$ after LTP induction were averaged for statistical analysis. Data were analyzed using a two-way ANOVA, followed by Bonferroni's post hoc test in GraphPad Prism 5.

Conditioned place aversion test. Mice were placed into an enclosed Plexiglas alleyway $(40 \times 10 \times 21 \mathrm{~cm})$, the floor of which was divided into blue (26.5 cm long; True Blue \#196; Lee Filters) and orange $(13.5 \mathrm{~cm}$ long; Orange \#105; Lee Filters) zones. After a 5 min habituation period, the duration of time spent in the blue and orange zones was quantified during three consecutive 5 min observation periods. In the first (prelight), no light stimulus was given. In the second (light), a strobe light (Giga Strobe halogen stage lamp, $1200 \mathrm{~W}, 5 \mathrm{~Hz}$; Geni Electronics) pulsed light through the glass floor. The strobe light was turned off immediately before the final (post-light) observation period. To investigate whether morphine is capable of reversing or reducing the aversion to blue light, a group of morphine-injected $\mathrm{Na}_{v} 1.8-\mathrm{ChR}^{+}$mice was tested for conditioned place aversion (CPA) under the same experimental setup, with a slight variation in the length of the blue and orange zones (blue, $13 \mathrm{~cm}$ long; orange, $13 \mathrm{~cm}$ long). Morphine was injected intraperitoneally at 10 $\mathrm{mg} / \mathrm{kg}$. Morphine-treated mice were compared with a group of salineinjected $\mathrm{Na}_{v} 1.8-\mathrm{ChR}^{+}$animals. The time spent in the blue-lit area in each condition (pre-light, light, and post-light) was reported, and statistical significance was analyzed using the multiple $t$ tests comparison corrected with the Sidak-Bonferroni method in GraphPad Prism 6.

\section{Results}

\section{Cellular distribution of ChR2-EYFP}

To characterize the cellular distribution of the transgenic ChR2EYFP channels in sensory ganglia of $N a_{v} 1.8-C h R 2^{+}$mice, we performed immunohistochemistry experiments using the puri- 

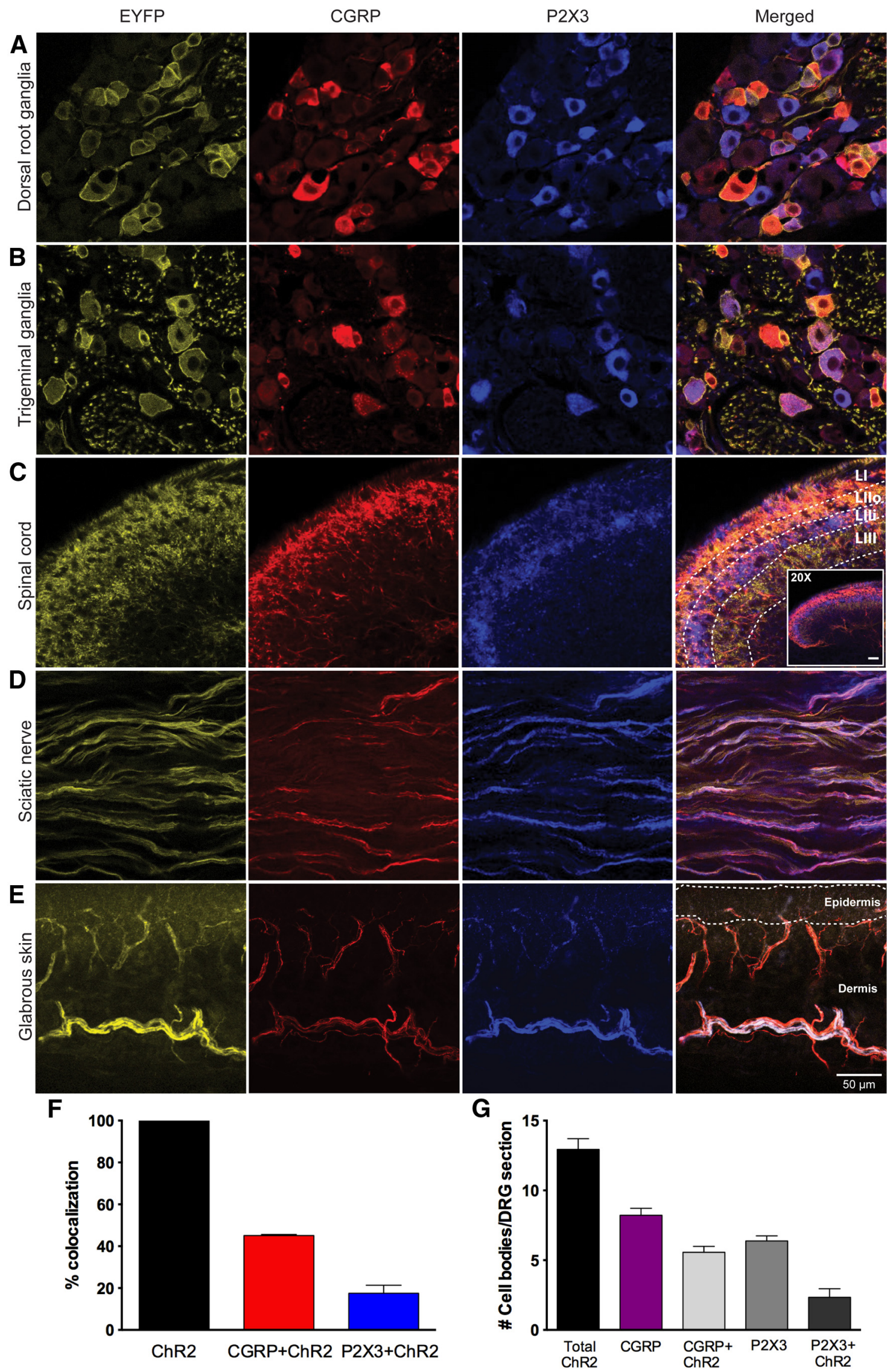

Figure 1. Distribution of ChR2-EYFP channels in peripheral sensory pathways of $\mathrm{Na}_{v} 1.8-\mathrm{ChR2}{ }^{+}$mice. The first column of confocal micrographs shows the fluorescence of the ChR2-EYFP construct (yellow), the second shows (GRP immunostaining (red), the third represents the P2X3 labeling pattern (blue), and the fourth shows the merge. ChR2-EYFP colocalizes with the nonpeptidergic (P2X3) and peptidergic (CGRP) nociceptive markers in DRG (A) and TG (B) neurons. C, EYFP fluorescence overlaps with CGRP labeling in laminae I and II and (Figure legend continues.) 
A ChR2-EYFP

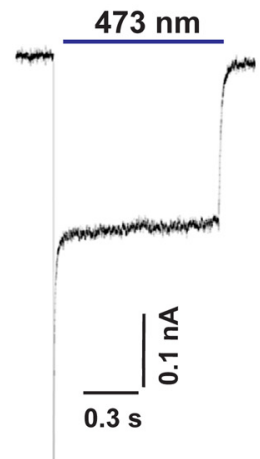

B $2 \mathrm{~Hz}$ stimulation

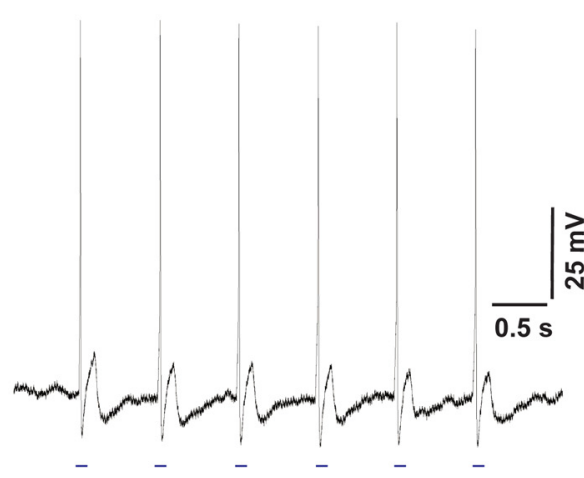

C $5 \mathrm{~Hz}$ stimulation

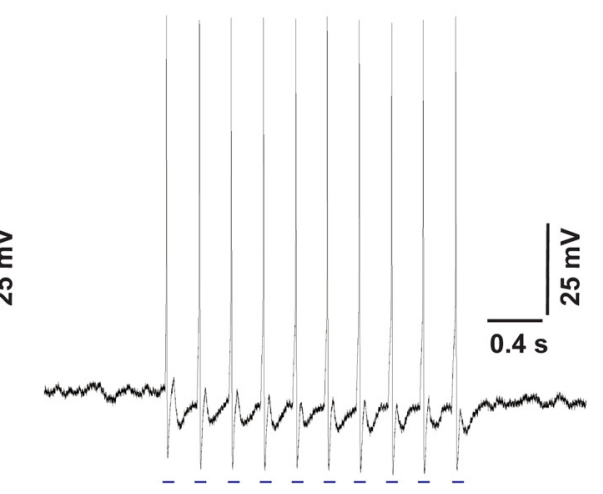

F 2 Hz stimulation
D $10 \mathrm{~Hz}$ stimulation

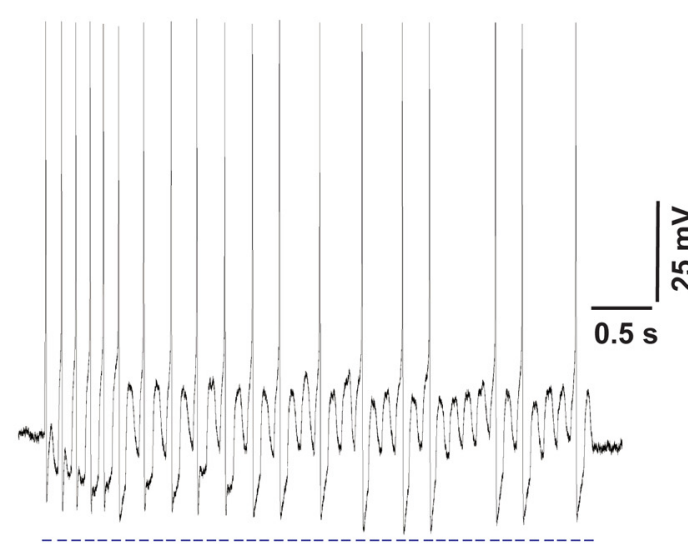

E
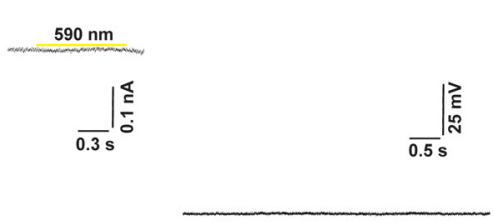

G

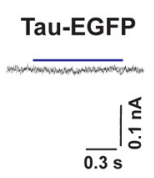

H 2 Hz stimulation

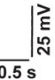

Figure 2. Light-evoked responses in ChR2-EYFP ${ }^{+}$DRG neurons. $A$, Representative blue light-induced photocurrent $(473 \mathrm{~nm})$. The duration of the optical stimulation is $1 \mathrm{~s}$, and the intensity is $0.25 \mathrm{~mW} / \mathrm{mm}^{2}$. $\boldsymbol{B}-\boldsymbol{D}$, Blue light-evoked action potentials in ChR2 ${ }^{+}$DRG neurons at frequencies of 2,5 , and $10 \mathrm{~Hz}$, with $50 \mathrm{~ms}$ pulse duration. $\boldsymbol{E}, \boldsymbol{F}$, Absence of photocurrent and membrane depolarization in ChR2 ${ }^{+}$neurons stimulated with $590 \mathrm{~nm}$ yellow light. $\boldsymbol{G}, \boldsymbol{H}$, Absence of photocurrent and membrane depolarization in Tau-EGFP ${ }^{+}$neurons stimulated with blue light $(0.25$ $\mathrm{mW} / \mathrm{mm}^{2}$ ). Cells were held at $-60 \mathrm{mV}$ in voltage clamp, and the RMP was -55 to $-65 \mathrm{mV}$ in current-clamp configuration ( $n=5-10$ cells).

nergic receptor $\mathrm{P} 2 \mathrm{X} 3$ and CGRP as nonpeptidergic and peptidergic nociceptive markers, respectively. Strong EYFP labeling was observed at the plasma membrane of cell soma in small- and medium-diameter DRG and TG neurons (Fig. $1 A, B$ ). P2X3 and CGRP patterns were mutually exclusive, but P2X3- and CGRPimmunopositive neurons greatly overlapped with $\mathrm{EYFP}^{+}$neurons (Fig. $1 A, B$ ). Similarly, EYFP fluorescence was observed in laminae I and II of the dorsal horn of the spinal cord, overlapping with both CGRP labeling in laminae $\mathrm{I}_{\text {and }} \mathrm{II}_{\mathrm{o}}$ and P2X3 labeling in lamina $\mathrm{II}_{\mathrm{i}}$ (Fig. $1 C$ ). This distribution shows the trafficking of ChR2 channels along the $\mathrm{C}$ and $\mathrm{A} \delta$ fibers of the nociceptive primary afferents projecting from the DRG to the dorsal horn. We noticed that EYFP labeling extended ventrally deeper than P2X3 labeling (Fig. 1C), covering an area innervated by myelinated$$
\leftarrow
$$

(Figure legend continued.) P2X3 labeling in lamina $\mathrm{I}_{\mathrm{i}}$ of the dorsal horn, showing the trafficking of ChR2-EYFP along $C$ and A $\delta$ nociceptive fibers from DRG to spinal cord. EYFP fluorescence in lamina III indicates the expression of ChR2 in a subpopulation of non-nociceptive neurons. $\boldsymbol{D}$, ChR2-EYFP is transported throughout CGRP ${ }^{+}$peptidergic and $\mathrm{P} 2 \mathrm{X}^{+}{ }^{+}$nonpeptidergic fibers in the sciatic nerve and colocalizes with CGRP and P2X3 in free nerve endings in the lower and upper dermis of glabrous skin $(\boldsymbol{E})$, indicating the efficient transport of ChR2-EYFP channels from DRG cell somata to their peripheral targets. Lamination of the dorsal horn of spinal cord and glabrous skin layers is indicated on merged panels. Scale bars, $50 \mu \mathrm{m} . \boldsymbol{F}, \mathbf{G}$, Quantification (mean + SEM) of the overlap between ChR2-EYFP and the nociceptive markers P2X3 and CGRP in DRG neurons of $\mathrm{Na}_{v} 1.8$ - ChR2 ${ }^{+}$mice ( $n=4$ mice, 8 sections per mouse).
}

fibers (lamina III). Quantification of the overlap between the peptidergic and nonpeptidergic markers and ChR2-EYFP in DRG neurons of $\mathrm{Na}_{v} 1.8-\mathrm{ChR} 2^{+}$mice revealed that $45.1 \pm 0.52 \%$ of EYFP $^{+}$cells were CGRP ${ }^{+}$, whereas $67.53 \pm 1.75 \%$ of CGRP ${ }^{+}$ neurons were $\mathrm{EYFP}^{+}$. Conversely, $17.54 \pm 3.81 \%$ of $\mathrm{EYFP}^{+}$cells were $\mathrm{P} 2 \mathrm{X} 3^{+}$, whereas $35.65 \pm 7.0 \%$ of $\mathrm{P} 2 \mathrm{X} 3^{+}$neurons were $\mathrm{EYFP}^{+}$(Fig. $1 F, G$ ). These results are consistent with a recent study showing that $\mathrm{Na}_{\mathrm{v}} 1.8$ is not restricted to nociceptors but is also expressed in a subpopulation of low-threshold mechanoreceptors with $\mathrm{C}$ and myelinated $\mathrm{A} \beta$ fibers (Shields et al., 2012). However, the colocalization of ChR2-EYFP with nociceptive markers, particularly P2X3, was lower than the reported overlap of $\mathrm{Na}_{\mathrm{v}} 1.8$ with these markers in DRG neurons (Shields et al., 2012). This discrepancy could be attributed to the different genetic background of the ChR2-carrying mouse line. ChR2 was effectively transported to the periphery, in which EYFP fluorescence overlapped with $\mathrm{P} 2 \mathrm{X}^{+}{ }^{+}$and CGRP ${ }^{+}$afferent fibers in the sciatic nerve (Fig. 1D) and terminated in the deep and superficial layers of the glabrous skin bordering the dermal-epidermal junction (Fig. 1E).

\section{Functionality of ChR2-EYFP channels in DRG neurons}

Patch-clamp recordings were conducted to test the functionality of the optogenetic ChR2-EYFP construct in cultured DRG neurons from $\mathrm{Na}_{v} 1.8-C h R 2^{+}$mice. Large inward photocurrents $(23.17 \pm 6.52 \mathrm{pA} / \mathrm{pF})$ with typical ChR2 kinetics were induced in 
A

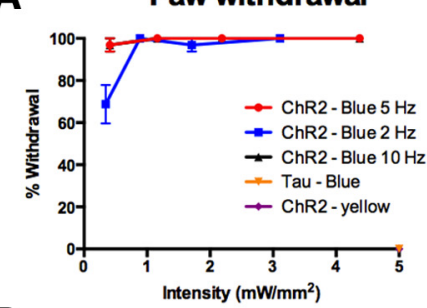

B

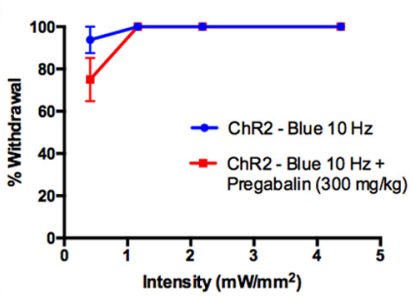

C

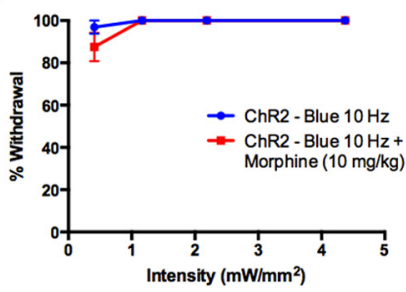

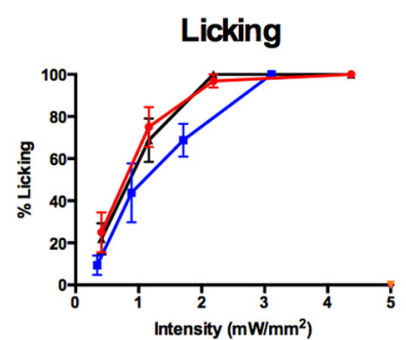
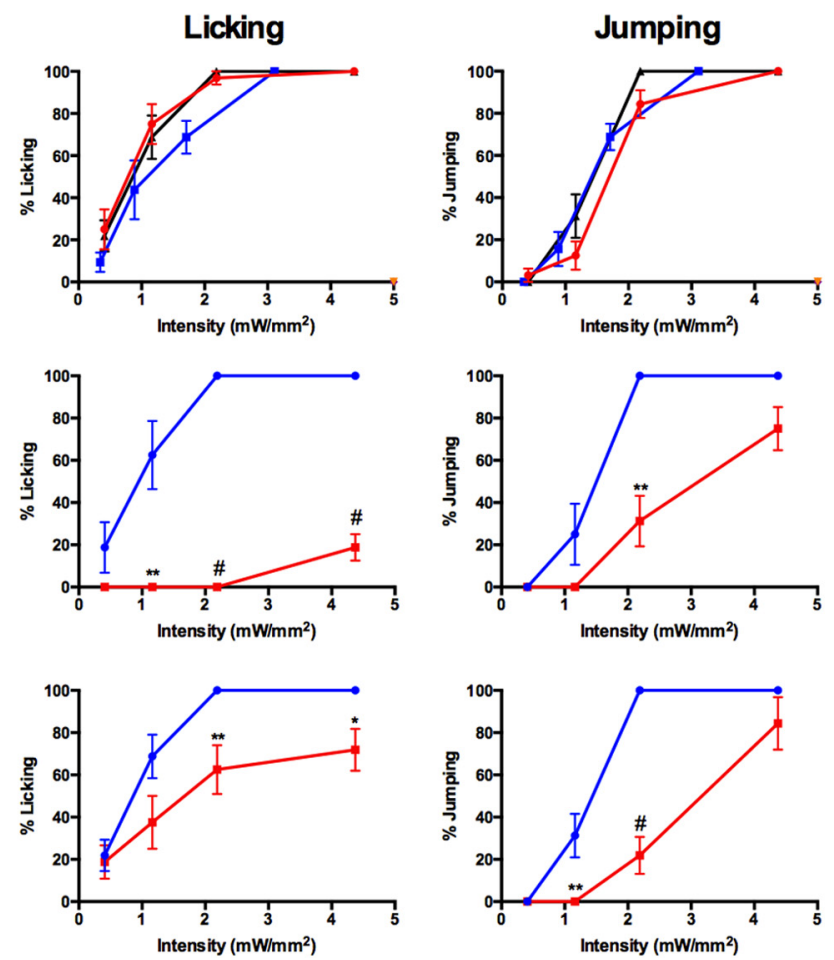

Vocalization
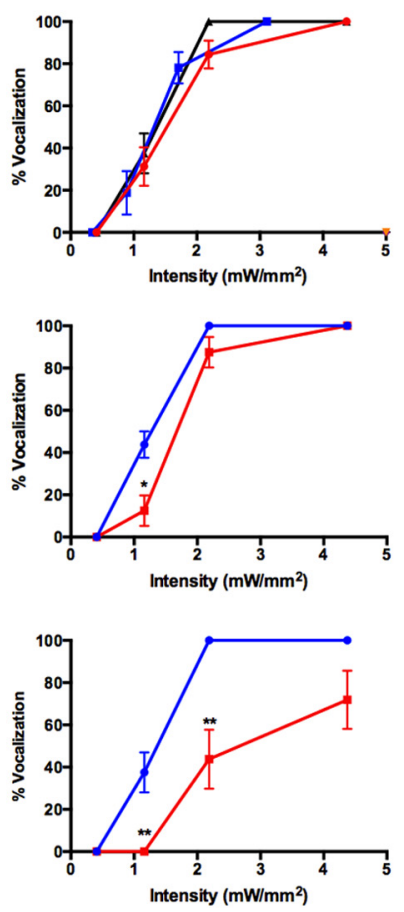

Figure 3. Acute behavioral characterization of $\mathrm{Na}_{v} 1.8-\mathrm{ChR2}{ }^{+}$mice. $A$, Nocifensive behaviors displayed by $\mathrm{Na}_{v} 1.8-\mathrm{ChR2}^{+}$and $\mathrm{Na}_{v} 1.8-\mathrm{Tau}^{+}$mice during acute wavelength-, intensity-, and frequency-specific laser light stimulation. Pregabalin $(\boldsymbol{B})$ and morphine $(\boldsymbol{C})$ decreased some nocifensive behaviors in $\mathrm{Na}_{v} 1.8-\mathrm{ChR2^{+ }}$ mice. Symbols represent mean \pm SEM percentage of stimulations featuring the behavior ( $n=5-8$ mice per genotype, $n=4-8$ mice per drug). Statistical significance was analyzed using multiple $t$ tests corrected with the Holm-Sidak method, ${ }^{*} p<$ $0.05,{ }^{* *} p<0.01,{ }^{\#} p<0.0001$.

$\mathrm{EYFP}^{+}$neurons under blue-light $(473$ nm) stimulation (Fig. 2A). These photocurrents were absent under yellow-light $(590 \mathrm{~nm})$ stimulation, in accordance with the spectral properties of ChR2 (Mattis et al., 2011; Fig. 2E,F). Blue light failed to evoke photocurrents in DRG neurons from $\mathrm{Na}_{v} 1.8-\mathrm{Tau}^{+}$control mice (Fig. $2 G, H)$. ChR2-mediated photocurrents translated into single action potentials reliably generated at increasing frequencies, up to $5 \mathrm{~Hz}$ (Fig. $2 \mathrm{~B}, \mathrm{C}$ ). Fidelity of action potentials was partially lost at higher stimulation frequencies, such as $10 \mathrm{~Hz}$ (Fig. $2 D)$. These findings are consistent with the phasic firing properties of primary sensory neurons (Wang and McKinnon, 1995) and the fidelity of light-induced action potentials at different frequencies reported in rat DRG mechanoreceptors/ proprioceptors (Campagnola et al., 2008; Ji et al., 2012). Given the low unitary conductance of ChR2 channels ( $<300 \mathrm{fS}$; Lin, 2011) and the large inward photocurrents measured here, our electrophysiological results indicate an efficient translocation of ChR2 channels to the plasma membrane, which may allow direct optical activation of nociceptors in vivo. This strong ChR2-EYFP expression did not alter the basic membrane properties of small DRG neurons in $\mathrm{Na}_{v} 1.8-\mathrm{ChR} 2^{+}$mice, such as membrane capacitance $\left(C_{\mathrm{m}}\right)$, resting membrane potential (RMP), and input resistance $\left(R_{\mathrm{in}}\right)$. ChR2 ${ }^{+} \mathrm{DRG}$ neurons had a $C_{\mathrm{m}}, \mathrm{RMP}$, and $R_{\mathrm{in}}$ of $19.91 \pm 2.18 \mathrm{pF},-62.09 \pm 2.83 \mathrm{mV}$, and $0.8 \pm 0.1 \mathrm{G} \Omega$, respectively, whereas $\mathrm{ChR} 2^{-}$DRG neurons from
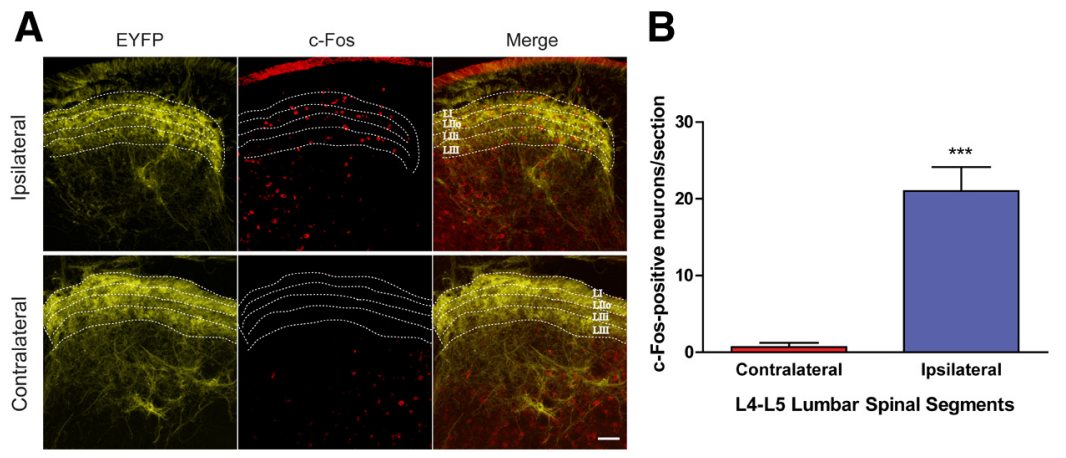

Figure 4. Activation of second-order neurons in the dorsal horn of the lumbar spinal cord. $\boldsymbol{A}$, Ipsilateral c-Fos expression in neurons of laminae I-III of the dorsal horn after 10 min suprathreshold blue-light stimulation of the left hindpaw of $\mathrm{Na}_{v} 1.8-$ $\mathrm{ChR2}^{+}$mice. c-Fos ${ }^{+}$neurons colocalize with EYFP ${ }^{+}$peptidergic, nonpeptidergic, as well as non-nociceptive afferent fibers, showing the simultaneous activation of these fibers by blue light. Lamination of the dorsal horn layers is indicated on merged panels. Scale bar, $50 \mu \mathrm{m}$. B, Quantification of ${\mathrm{C}-F o S^{+}}^{+}$neurons in laminae I-III of the L4-L5 lumbar spinal segments from stimulated $\mathrm{Na}_{v} 1.8-\mathrm{ChR2}{ }^{+}$mice. Data are expressed as mean $\pm \mathrm{SEM}\left({ }^{* * *} p<0.001\right.$, unpaired Student's $t$ test) of the number of $c-$ Fos ${ }^{+}$neurons per section on the ipsilateral versus contralateral sides of the spinal cord ( $n=4$ mice, 10 sections per mouse).

control littermate $N a_{v} 1.8-$ Cre mice had a $C_{\mathrm{m}}$, RMP, and $R_{\text {in }}$ of $21.33 \pm 4.91 \mathrm{pF},-61.67 \pm 3.18 \mathrm{mV}$, and $0.72 \pm 0.12 \mathrm{G} \Omega$, respectively (unpaired Student's $t$ test, $p>0.6$ for all parameters, $n=9-11$ cells).

\section{Acute light-induced behavioral responses}

We next tested whether $N a_{v} 1.8-C h R 2^{+}$mice exhibit nocifensive behaviors in response to blue-light exposure. Paw withdrawal, paw licking, jumping, and audible vocalization were robustly evoked by exposure of the glabrous skin of the hindpaws to blue light in freely moving mice. We characterized the stimulusintensity profile of these nocifensive behaviors at three different 
A

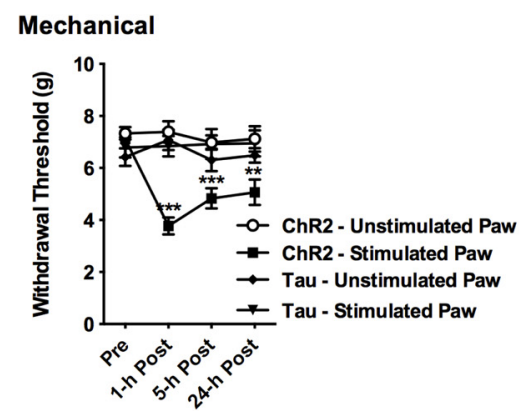

C

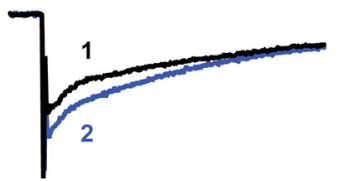

D

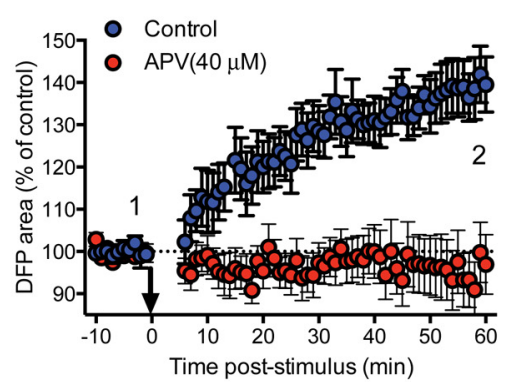

$\mathbf{F}$

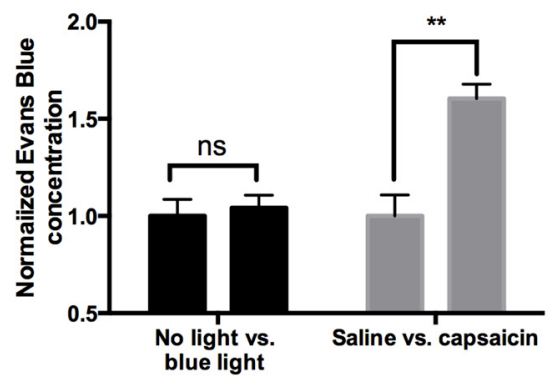

Figure 5. Long-term sensitization of sensory pathways in $\mathrm{Na}_{v} 1.8-\mathrm{ChR2}^{+}$and $\mathrm{Na}_{v} 1.8-\mathrm{Tau}^{+}$mice. $\boldsymbol{A}, \boldsymbol{B}$, Prolonged, suprathreshold blue-light exposure $\left(30 \mathrm{~min}, 2 \mathrm{~Hz}, 2.34 \mathrm{~mW} / \mathrm{mm}^{2}\right)$ of the left hindpaw of anesthetized $\mathrm{Na}_{v} 1.8-\mathrm{ChR2}^{+}$and $\mathrm{Na}_{v} 1.8-\mathrm{Tau}^{+}$ mice produces long-term mechanical $(\boldsymbol{A})$ and thermal $(\boldsymbol{B})$ hypersensitivity lasting up to $24 \mathrm{~h}$ after stimulation in $\mathrm{Na}_{\mathrm{v}} 1.8-\mathrm{ChR2}^{+}$ mice. Symbols represent mean \pm SEM threshold to hindpaw withdrawal to von Frey fibers and to hindpaw-withdrawal latency from noxious thermal stimulation (high-intensity white light) before (Pre) and after (1-h Post, 5-h Post, and 24-h Post) light stimulation ( $n=7-12$ mice per condition). Data were analyzed using the repeated-measures one-way ANOVA test. C, D, Blue light-induced LTP in the dorsal horn of $\mathrm{Na}_{v} 1.8-\mathrm{ChR2}{ }^{+}$mice. C, Average traces of DFPs recorded from acute spinal cord slices before (black) and after (blue) LTP induction and in the presence of the NMDA receptor blocker APV (red). D, Gradual increase in the area of DFPs after blue-light stimulation ( $2 \mathrm{~min}, 2 \mathrm{~mW}, 2 \mathrm{~Hz}$ ), reaching a $40 \%$ increase $60 \mathrm{~min}$ after stimulus compared with prestimulus measurements (baseline). This increase is completely abolished when APV ( $40 \mu \mathrm{M})$ is added during LTP induction. E, Quantification of the percentage change in the area of DFPs in the presence (red) and absence (blue) of APV, before (Baseline) and 55-60 min after (LTP) LTP induction ( $n=6-7$ per condition). Data are expressed as mean \pm SEM and analyzed using two-way ANOVA, followed by Bonferroni's post hoc test. $\boldsymbol{F}$, Evans blue plasma extravasation after subdermal capsaicin (1\%) injection in the hindpaw of $\mathrm{Na}_{v} 1.8-\mathrm{Tau}^{+}$mice and after prolonged blue-light stimulation $\left(30 \mathrm{~min}, 2 \mathrm{~Hz}, 2.34 \mathrm{~mW} / \mathrm{mm}^{2}\right)$ of the hindpaw of anesthetized $\mathrm{Na}_{v} 1.8-\mathrm{ChR2}{ }^{+}$mice. Evans blue concentration was normalized in reference to each internal control (saline injection for capsaicin and no stimulation for the blue-light exposure; $n=4-5$ mice per condition). ${ }^{*} p<0.05$, ${ }^{* *} p<0.01$, ${ }^{* *} p<0.001$.

pulsing frequencies: 2,5 , and $10 \mathrm{~Hz}$. No significant difference was observed in the behavioral profile of $\mathrm{Na}_{v} 1.8-\mathrm{ChR} 2^{+}$mice among the three stimulation paradigms. Paw withdrawal and licking occurred at a light intensity of $0.34 \mathrm{~mW} / \mathrm{mm}^{2}$, whereas jumping and vocalization appeared at $0.9 \mathrm{~mW} / \mathrm{mm}^{2}$. All four behaviors were reliably evoked at intensities of $4.4 \mathrm{~mW} / \mathrm{mm}^{2}$ and higher, for all pulsing frequencies. None of these behaviors were produced with yellowlight stimulation at the highest intensity $\left(>4.5 \mathrm{~mW} / \mathrm{mm}^{2}\right)$, nor in $\mathrm{Na}_{v} 1.8-\mathrm{Tau}^{+}$ mice under blue-light excitation (Fig. $3 A$ ). These responses were greatly reduced by centrally acting analgesics, such as morphine and pregabalin, at nonsedating doses (riding time on the rotarod: before morphine injection, $264.7 \pm 34.1 \mathrm{~s} ; 30$ min after injection, $234.7 \pm 27.7 \mathrm{~s} ; 60 \mathrm{~min}$ after injection, $271.7 \pm 67.7 s ; p=0.5403$, repeated-measures one-way ANOVA, $n=3$ mice; Fig. $3 B, C)$. Paw withdrawal was not blocked by these analgesic drugs, suggesting that this behavior is predominantly driven by the activation of nonnociceptive neurons expressing ChR2. Finally, a subdermal injection of lidocaine (2\%) reduced some light-induced nocifensive behaviors at low stimulation intensities (at $0.9 \mathrm{~mW} / \mathrm{mm}^{2}$; percentage licking, $83.3 \pm 11.2$ before lidocaine injection vs $41.7 \pm 14.9$ after injection; $p<$ $0.05, n=4$ mice).

\section{Light-mediated activation of second- order sensory neurons}

To determine which nociceptive fibers are conducting the noxious signals from the periphery to the CNS, we looked at c-Fos expression in second-order sensory neurons in the dorsal horn of the spinal cord. A prolonged (10 $\mathrm{min})$ suprathreshold blue-light stimulation of the left hindpaw of $\mathrm{Na}_{v} 1.8-\mathrm{ChR} 2^{+}$mice induced c-Fos expression in the superficial laminae of the ipsilateral side of the dorsal horn (Fig. $4 A$ ). The c-Fos activation pattern is consistent with the activation of both peptidergic fibers that project to laminae I and $\mathrm{II}_{\mathrm{o}}$ and nonpeptidergic fibers that project to lamina $\mathrm{II}_{\mathrm{i}}$, demonstrating that $\mathrm{ChR} 2$ is being activated in both types of fibers in $\mathrm{Na}_{v} 1.8-\mathrm{ChR} 2^{+}$mice. Furthermore, c-Fos labeling was detected in lamina III of the dorsal horn, indicating that blue-light stimulation of the hindpaw activates nonnociceptive terminals in $N a_{v} 1.8-C h R 2^{+}$ mice. This finding fits with our previous data showing the fluorescence of ChR2EYFP in sensory afferents projecting to lamina III and the presence of $\mathrm{ChR} 2^{+}$ DRG neurons that do not express nociceptive markers. It further correlates with the lack of sensitivity of paw withdrawal to central analgesics, suggesting that bluelight stimulation is activating a subpopulation of mechanoreceptors at the peripheral terminals. As expected, the number of c-Fos-immunoreactive neurons was significantly lower on the contralateral side $(21.03 \pm 3.11$ ipsilateral vs $0.7 \pm 0.53$ contralateral, $p=0.0007$, unpaired Student's $t$ test, $n=4$ mice, 10 sections/mouse; Fig. $4 A, B$ ). Given that $\mathrm{c}$-Fos is a neuronal marker 
for synaptic activation, these findings define the synaptic connectivity responsible for light-induced behaviors, which could be the site of neural plasticity underlying pain hypersensitivity under chronic conditions.

\section{Optogenetic induction of long-term sensitization}

To investigate whether optogenetic stimulation of $\mathrm{Na}_{\mathrm{v}} 1.8^{+}$afferents can induce mechanical and thermal sensitization, the plantar surfaces of the left hindpaw of anesthetized $\mathrm{Na}_{v} 1.8-\mathrm{ChR}^{+}$mice were exposed to a prolonged suprathreshold blue-light stimulation ( $30 \mathrm{~min}, 2 \mathrm{~Hz}, 2.34$ $\mathrm{mW} / \mathrm{mm}^{2}$ ) and then tested for changes in mechanical and thermal sensitivity. $N a_{v} 1.8-C h R 2^{+}$mice displayed thermal and mechanical hypersensitivity of their left hindpaw at 1, 5, and $24 \mathrm{~h}$ after stimulation compared with baseline measurements, whereas the sensitivity of the right hindpaw remained unchanged across the different time points (Fig. 5A,B). Also, the same optical stimulation did not affect the thermal and mechanical thresholds of the stimulated hindpaw of $\mathrm{Na}_{v} 1.8-$ $\mathrm{Tau}^{+}$control mice, demonstrating that the detected hypersensitivity in $\mathrm{Na}_{v} 1.8-\mathrm{ChR} 2^{+}$animals is ChR2-dependent (Fig. $5 \mathrm{~A}, \mathrm{~B}$ ). Interestingly, although peptidergic terminals are activated by blue light, no signs of neurogenic inflammation were detected under these experimental conditions. Our plasma extravasation data show no significant difference in Evans blue concentration between the optically stimulated and the nonstimulated hindpaws of $\mathrm{Na}_{v} 1.8-\mathrm{ChR} 2^{+}$mice $(5.43 \pm 5.49 \%$ increase, $p=0.7046$, unpaired Student's $t$ test, $n=5$ mice; Fig. $5 F$ ). This result is consistent with the lack of any visible edema in the optically stimulated hindpaws of $\mathrm{Na}_{v} 1.8-\mathrm{ChR} 2^{+}$mice, whereas capsaicininjected hindpaws of $\mathrm{Na}_{v} 1.8-\mathrm{Tau}^{+}$mice display clear edema and a significant increase in Evans blue concentration compared to saline condition (63.4 $\pm 9.4 \%$ increase, $p=0.0035$, unpaired Student's $t$ test, $n=4$ mice; Fig. $5 F$ ). These findings demonstrate that long-term sensitization of specific sensory pathways can be optogenetically achieved without any signs of peripheral inflammation or tissue damage.

LTP of synaptic connections between primary afferents and neurons of the superficial dorsal horn may be a substrate of hyperalgesia (Ruscheweyh et al., 2011) and could explain the pain hypersensitivity observed after prolonged stimulation. Thus, we tested whether light-mediated activation of ChR2 afferents can induce LTP at primary afferent synapses in the superficial dorsal horn.

DFPs were evoked by brief (10 ms) blue-light stimulations of the dorsal roots (Fig. 5C). LTP was induced using a lowfrequency $(2 \mathrm{~Hz}, 2 \mathrm{~min}, 2 \mathrm{~mW})$ stimulation protocol. Under control conditions, and similar to previous reports (Ikeda et al., 2006), LTP of DFPs was indicated by a gradual increase in the DFP area (Fig. 5D) over time (percentage increase from baseline is $\sim 40 \% 55-60 \mathrm{~min}$ after LTP, $p<0.001$, two-way ANOVA, followed by Bonferroni's post hoc test). The addition of the NMDA receptor blocker APV $(40 \mu \mathrm{M})$ during LTP induction completely prevented the potentiation of DFP area (Fig. $5 C-E$ ), similar to the NMDA dependence of electrically induced LTP in the dorsal horn (Ruscheweyh et al., 2011).

These results show that NMDA receptor-dependent LTP can be light induced in the dorsal horn of $\mathrm{Na}_{v} 1.8-\mathrm{ChR}^{+}$mice and could explain the thermal and mechanical behavioral hypersensitivity observed in behaving animals after their sensitization to blue light.

\section{Aversive conditioning to blue light}

We next asked whether light-induced activation of ChR2expressing afferents could be used as a conditioning stimulus. We tested whether $\mathrm{Na}_{v} 1.8-\mathrm{ChR} 2^{+}$mice would develop an aversion to a blue-lit area. In an alleyway consisting of blue- and orange-lit floors, blue-light exposure rapidly produced CPA such that $\mathrm{Na}_{v} 1.8-\mathrm{ChR}^{+}$mice learned to avoid the blue zone (Fig. 6A). These mice generally avoided the blue floor after stepping onto it a single time. Conversely, $\mathrm{Na}_{v} 1.8-\mathrm{Tau}^{+}$mice showed no preference for blue- or orange-lit floors across all time points (Fig. 6A). The aversion to blue light was partially reversed by morphine (10 $\mathrm{mg} / \mathrm{kg}$ ) in $\mathrm{Na}_{v} 1.8-\mathrm{ChR} 2^{+}$mice, because they spent more time in the blue zone during and after stimulation than the saline-injected $\mathrm{Na}_{v}$ 1.8-ChR2 $2^{+}$animals (Fig. 6B). This incomplete reversal could be explained by a morphine-insensitive unpleasantness caused by the optical activation of non-nociceptive subpopulations of afferents. Also, morphine may not block completely the nociceptive signals under strong blue-light stimulation, which could reduce its efficacy in reversing $\mathrm{CPA}$.

\section{Discussion}

Using a binary genetic approach, we developed a novel transgenic model in which pain is optically and non-invasively induced and remotely (without implantation of optical devices) controlled in awake, behaving animals. Previous attempts to optically control the activity of nociceptors in rodents failed to induce behavioral responses attributable to the low expression levels of excitatory opsins (Wang and Zylka, 2009). To overcome this obstacle, we used the $N a_{v} 1.8-C r e$ transgenic mouse line to deliver ChR2 channels to peripheral nociceptors, taking advantage of the strong CAG promoter driving their conditional expression. This strategy proved to be effective for expressing high levels of functional ChR2 channels in $\mathrm{Na}_{\mathrm{v}} 1.8^{+}$sensory neurons. Despite the low conductance $(<300 \mathrm{fS})$ of ChR2 channels (Lin, 2011), blue-light stimulation induced large inward photocurrents and was sufficient to generate action potentials in $\mathrm{EYFP}^{+}$DRG neurons. Furthermore, ChR2 expression was not restricted to the cell soma, but channels were trafficked along afferent fibers, reaching the superficial layers of the skin and the dorsal horn of the spinal cord. $\mathrm{EYFP}^{+}$fibers innervated the superficial laminae of the dorsal horn, mainly laminae I and II. However, a portion of lamina III also received input from $\mathrm{Na}_{\mathrm{v}} 1.8^{+}$fibers, suggesting that ChR2 
expression could extend to non-nociceptive subpopulations of DRG neurons. This observation was further supported by the quantification of the overlap between ChR2-EYFP and the nociceptive markers P2X3 and CGRP in DRG neurons, showing that $\sim 37 \%$ of $\mathrm{EYFP}^{+}$neurons did not colocalize with any of these markers. These findings are consistent with previous investigations of the selectivity of the $\mathrm{Na}_{\mathrm{v}} 1.8$ promoter, arguing that $\mathrm{Na}_{\mathrm{v}} 1.8$ is not confined to nociceptors but is also present in a proportion of myelinated and unmyelinated low-threshold mechanoreceptors (Shields et al., 2012). Although we do not rule out the optical stimulation of some mechanoreceptors in our model, our physiological and behavioral data demonstrate that blue light is effectively activating peripheral pain pathways in $\mathrm{Na}_{v} 1.8-\mathrm{ChR}^{+}$mice.

The activation of ChR2-expressing afferents with blue light translated into robust nocifensive responses ranging from paw withdrawal and licking to jumping and audible vocalization. The stimulus-intensity behavioral profiles of $\mathrm{Na}_{v} 1.8-C h R 2^{+}$mice were similar under three different pulsing frequencies, 2,5 , and $10 \mathrm{~Hz}$, demonstrating that the light-elicited behaviors are frequency-independent. However, the effect of varying the pulsing frequency may be undermined under acute behavioral testing attributable to the immediate withdrawal and the mobility of the animals after blue-light exposure, which prevents the experimenter from keeping the light stimulus on a specific target continuously. With the exception of paw withdrawal, all behavioral responses were sensitive to central analgesics, such as morphine and pregabalin. These results suggest that paw withdrawal could be related to the optogenetic activation of $\mathrm{Na}_{\mathrm{v}} 1.8^{+}$mechanoreceptors, whereas the rest of the observed behaviors are predominantly nociceptive.

Light-evoked responses likely resulted from the simultaneous activation of peptidergic, nonpeptidergic, and some non-nociceptive fibers, because their central inputs induced c-Fos expression in second-order neurons located in laminae I-III of the dorsal horn of the spinal cord. This simultaneous activation defines a useful property of the model that facilitates the investigation of the pain circuitry by optically activating the peripheral terminals and tracking their central connectivity. Furthermore, the use of blue light as a noxious stimulus prevents the direct activation of most non-nociceptive neuronal (e.g., thermoreceptors, proprioceptors) and non-neuronal (e.g., mast cells, macrophages, keratinocytes) cell populations, allowing the specific investigation of the $\mathrm{Na}_{\mathrm{v}} 1.8^{+}$neuronal component of peripheral pain pathways.

Peripheral blue-light stimulation not only evoked acute pain responses but also caused central sensitization of nociceptive pathways after prolonged exposure. Interestingly, no signs of neurogenic inflammation were detected after the prolonged optical stimulation. The lack of plasma extravasation could indicate that light-evoked central sensitization is mainly mediated by a nonpeptidergic subpopulation of ChR2 ${ }^{+} \mathrm{Na}_{\mathrm{v}} 1.8^{+}$fibers that do not release inflammatory neuropeptides. Alternatively, in the case of an effective stimulation of peptidergic afferents, the release of inflammatory mediators could be linked to the activation of specific intracellular pathways that are not activated by ChR2induced depolarizations. Finally, the simultaneous activation of different classes of sensory afferents, which is not the case in TRPV1-dependent capsaicin-induced neurogenic inflammation, could have an anti-inflammatory effect.

We further showed that LTP can be optically induced in the dorsal horn of the spinal cord. The use of optogenetic effectors to activate nociceptors has several advantages over the electrical stimulation of dorsal roots used to study LTP in vitro and in vivo.
The electrical stimulation of the dorsal root is nonspecific, because $\mathrm{C}$ fibers are only activated at stimulus intensities much higher than that required for activation of $\mathrm{A} \beta$ or $\mathrm{A} \delta$ fibers. Therefore, the development of optogenetic models in which peripheral nociceptors are targeted allows a more specific investigation of nociceptive fibers, particularly $\mathrm{C}$ fibers. Moreover, the use of light allows, for the first time, the same temporally precise patterns of nociceptor stimulation to induce both LTP and pain hypersensitivity. Using a variety of stimulation paradigms, our model could be further used to study plasticity in supraspinal pain centers and the deleterious effects of long-term exposure to pain on mouse behavior and CNS function.

Previous studies have investigated the role of $\mathrm{Na}_{\mathrm{v}} 1.8^{+}$neurons in acute, inflammatory, and neuropathic pain by ablating them or knocking out the $\mathrm{Na}_{\mathrm{v}} 1.8$ sodium channel gene (Lai et al., 2002; Zimmermann et al., 2007; Abrahamsen et al., 2008; Leo et al., 2010). With our transgenic approach, we can investigate whether the excitability and thus the physiological properties of $\mathrm{Na}_{\mathrm{v}} 1.8^{+}$neurons are altered under pathological and chronic pain conditions, by assessing the sensitivity of $\mathrm{Na}_{v} 1.8-\mathrm{ChR} 2^{+}$mice to blue light.

In conclusion, we developed a non-invasive model in which peripheral nociceptors are optically and remotely activated in behaving transgenic mice. This provides the first evidence of the optogenetic control of pain in behaving mammals, setting the ground for the development of a variety of transgenic models in which different excitatory and inhibitory opsins could be used to activate, modulate, or silence pain in vivo. Optical stimulation of sensory neurons in freely moving mammals will enhance the investigation of specific cellular components involved in pain transduction and sensitization in vivo, facilitating the development of novel therapeutic approaches for the treatment of intractable pain.

\section{References}

Abrahamsen B, Zhao J, Asante CO, Cendan CM, Marsh S, Martinez-Barbera JP, Nassar MA, Dickenson AH, Wood JN (2008) The cell and molecular basis of mechanical, cold, and inflammatory pain. Science 321:702-705. CrossRef Medline

Basbaum AI, Bautista DM, Scherrer G, Julius D (2009) Cellular and molecular mechanisms of pain. Cell 139:267-284. CrossRef Medline

Campagnola L, Wang H, Zylka MJ (2008) Fiber-coupled light-emitting diode for localized photostimulation of neurons expressing channelrhodopsin-2. J Neurosci Methods 169:27-33. CrossRef Medline

Dahlhaus A, Ruscheweyh R, Sandkühler J (2005) Synaptic input of rat spinal lamina I projection and unidentified neurones in vitro. J Physiol 566: 355-368. CrossRef Medline

Dubin AE, Patapoutian A (2010) Nociceptors: the sensors of the pain pathway. J Clin Invest 120:3760-3772. CrossRef Medline

Fenselau H, Heinke B, Sandkühler J (2011) Heterosynaptic long-term potentiation at GABAergic synapses of spinal lamina I neurons. J Neurosci 31:17383-17391. CrossRef Medline

Hargreaves K, Dubner R, Brown F, Flores C, Joris J (1988) A new and sensitive method for measuring thermal nociception in cutaneous hyperalgesia. Pain 32:77-88. CrossRef Medline

Ikeda H, Stark J, Fischer H, Wagner M, Drdla R, Jäger T, Sandkühler J (2006) Synaptic amplifier of inflammatory pain in the spinal dorsal horn. Science 312:1659-1662. CrossRef Medline

Ji ZG, Ito S, Honjoh T, Ohta H, Ishizuka T, Fukazawa Y, Yawo H (2012) Light-evoked somatosensory perception of transgenic rats that express channelrhodopsin-2 in dorsal root ganglion cells. PLoS One 7:e32699. CrossRef Medline

Joshi SK, Mikusa JP, Hernandez G, Baker S, Shieh CC, Neelands T, Zhang XF, Niforatos W, Kage K, Han P, Krafte D, Faltynek C, Sullivan JP, Jarvis MF, Honore P (2006) Involvement of the TTX-resistant sodium channel Nav 1.8 in inflammatory and neuropathic, but not post-operative, pain states. Pain 123:75-82. CrossRef Medline 
Lai J, Gold MS, Kim CS, Bian D, Ossipov MH, Hunter JC, Porreca F (2002) Inhibition of neuropathic pain by decreased expression of the tetrodotoxin-resistant sodium channel, NaV1.8. Pain 95:143-152. CrossRef Medline

Leo S, D'Hooge R, Meert T (2010) Exploring the role of nociceptor-specific sodium channels in pain transmission using Nav1.8 and Nav1.9 knockout mice. Behav Brain Res 208:149-157. CrossRef Medline

Lin JY (2011) A user's guide to channelrhodopsin variants: features, limitations and future developments. Exp Physiol 96:19-25. CrossRef Medline

Madisen L, Mao T, Koch H, Zhuo JM, Berenyi A, Fujisawa S, Hsu YW, Garcia AJ 3rd, Gu X, Zanella S, Kidney J, Gu H, Mao Y, Hooks BM, Boyden ES, Buzsáki G, Ramirez JM, Jones AR, Svoboda K, Han X, Turner EE, Zeng H (2012) A toolbox of Cre-dependent optogenetic transgenic mice for light-induced activation and silencing. Nat Neurosci 15:793-802. CrossRef Medline

Mattis J, Tye KM, Ferenczi EA, Ramakrishnan C, O’Shea DJ, Prakash R, Gunaydin LA, Hyun M, Fenno LE, Gradinaru V, Yizhar O, Deisseroth K (2011) Principles for applying optogenetic tools derived from direct comparative analysis of microbial opsins. Nat Methods 9:159-172. CrossRef Medline

Ruscheweyh R, Wilder-Smith O, Drdla R, Liu XG, Sandkühler J (2011)
Long-term potentiation in spinal nociceptive pathways as a novel target for pain therapy. Mol Pain 7:20. CrossRef Medline

Shields SD, Ahn HS, Yang Y, Han C, Seal RP, Wood JN, Waxman SG, Dib-Hajj SD (2012) Navl.8 expression is not restricted to nociceptors in mouse peripheral nervous system. Pain 153:2017-2030. CrossRef Medline

Stirling LC, Forlani G, Baker MD, Wood JN, Matthews EA, Dickenson AH, Nassar MA (2005) Nociceptor-specific gene deletion using heterozygous NaV1.8-Cre recombinase mice. Pain 113:27-36. CrossRef Medline

Wang H, Zylka MJ (2009) Mrgprd-expressing polymodal nociceptive neurons innervate most known classes of substantia gelatinosa neurons. J Neurosci 29:13202-13209. CrossRef Medline

Wang HS, McKinnon D (1995) Potassium currents in rat prevertebral and paravertebral sympathetic neurones: control of firing properties. J Physiol 485:319-335. Medline

Yang K, Takeuchi K, Wei F, Dubner R, Ren K (2011) Activation of group I mGlu receptors contributes to facilitation of NMDA receptor membrane current in spinal dorsal horn neurons after hindpaw inflammation in rats. Eur J Pharmacol 670:509-518. CrossRef Medline

Zimmermann K, Leffler A, Babes A, Cendan CM, Carr RW, Kobayashi J, Nau C, Wood JN, Reeh PW (2007) Sensory neuron sodium channel Nav1.8 is essential for pain at low temperatures. Nature 447:855-858. CrossRef Medline 